\title{
Decreased Expression of the High Mobility Group Box 1 (HMGB1) Gene in Peripheral Blood in Patients with Mild or Moderate Clostridioides difficile Infection
}

\author{
Jacek Czepiel ${ }^{1, *(\mathbb{C})}$, Grażyna Biesiada ${ }^{1}$, Ewelina Pitera ${ }^{2}$, Paweł P. Wołkow ${ }^{2,3}{ }^{\circledR}$, \\ Mateusz Michalak ${ }^{4}$ and Aleksander Garlicki ${ }^{1}$ \\ 1 Department of Infectious and Tropical Diseases, Jagiellonian University Medical College, 30-688 Krakow, \\ Poland; gbiesiada@op.pl (G.B.); agarlicki@gmail.com (A.G.) \\ 2 Center for Medical Genomics OMICRON, Jagiellonian University Medical College, 31-034 Krakow, Poland; \\ ewelina.pitera@uj.edu.pl (E.P.); pawel.wolkow@uj.edu.pl (P.P.W.) \\ 3 Department of Pharmacology, Jagiellonian University Medical College, 31-531 Krakow, Poland \\ 4 Ludwik Rydygier Hospital in Krakow, 31-826 Krakow, Poland; michalakcontact@gmail.com \\ * Correspondence: jacek.czepiel@uj.edu.pl; Tel./Fax: +48-124-002022/17
}

Received: 21 July 2020; Accepted: 7 August 2020; Published: 11 August 2020

\begin{abstract}
Cytokines are mediators of inflammation induced in the course of Clostridioides difficile infection (CDI). High Mobility Group Box 1 (HMGB1) is a cytokine playing an important role in the pathogenesis of numerous inflammatory and autoimmune diseases. The aim of the study was to assess the HMGB1 gene expression in the course of CDI. We have performed a prospective case-control studyincluding 55 adult patients, among them 27 with CDI, who were hospitalized from October 2018 to February 2020 and 28 healthy volunteers. We assessed: a complete blood count with differential leukocyte count, blood creatinine, albumin, and C-reactive protein (CRP) levels. Then, the expression of the HMGB1 gene was evaluated using quantitative Real-Time PCR. Patients with CDI were found to have a significant increase in white blood cells (WBC), neutrophil count, and CRP levels, they also exhibited decreased levels of albumin compared with controls. The HMGB1 gene expression was significantly lower among patients with CDI compared with the control group and significantly, inversely correlated with CRP level in blood. In conclusion, we have observed a decreased expression of the HMGB1 gene in peripheral blood of patients with mild or moderate CDI, which hypothetically could reflect their diminished capability to fight the pathogen.
\end{abstract}

Keywords: genetic; infection; inflammation; pathogenesis

\section{Introduction}

Clostridioides difficile infection (CDI) is caused by anaerobic bacilli of the species Clostridioides difficile (C. difficile), formerly known as Clostridium difficile, widespread in the human environment [1]. In the last two decades, the incidence and severity of CDI have been growing worldwide, reinforcing it as one of the most eminent nosocomial infections of modern healthcare. Infection occurs through the fecal-oral route, the most important risk factors for the development of the disease are the use of antibiotics, hospitalization, and older age. The pathogen itself is not directly invasive- its virulence factors are enzymes it produces, such as collagenase, hyaluronidase, chondroitin sulfatase, and toxins, which destroy the intestinal epithelium cytoskeleton and stimulate adhesion of neutrophils to the intestinal wall, causing inflammation and loss of both the integrity and functionality of the intestinal mucosa. Cytokines: interleukin 8 (IL-8), interleukin $1 \beta$ (IL-1 $\beta$ ), interleukin 6 (IL-6), tumor necrosis factor $\alpha(\mathrm{TNF} \alpha)$, interferon $\gamma(\operatorname{IFN} \gamma)$, and leukotriene B4 also play an important part in CDI pathogenesis $[2,3]$. The clinical picture of CDI is diverse and ranges from asymptomatic carrier status, 
through various degrees of diarrhea, to most severe colitis often leading to death. The prevalence of C. difficile colonization during hospitalization correlates to the length of stay, and in a few weeks can reach even $50 \%$ of patients [3-6]. However only some become symptomatic [7], the reason for this remains unknown. Moreover, the severity of CDI may vary even between people similar in age and co-morbidities [8]. Genetic diversity, reflected in differences in immune system functionality of the patients may, at least partially, be a factor in CDI risk and/or variance of its course.

High Mobility Group Box 1 (HMGB1) is a cytokine located in the cell nucleus. There, it plays a vital part in maintaining chromosome structure and DNA damage prevention [9]. During the cellular stress response, it is released into the cytosol, and subsequently extracellularly, where it mediates the inflammatory, defense response and other cellular processes [9-11]. Efron et al. assessed genetic profiles of leukocytes in trauma patients, demonstrating an increased expression of the HMGB1 gene in the subgroup of patients who developed CDI [12].

Therefore, the aim of our study was to prospectively assess HMGB1 gene expression in the course of CDI.

\section{Materials and Methods}

\subsection{Study Population}

We prospectively studied 55 patients. The study group included 27 patients with mild or moderate CDI hospitalized at the Department of Infectious and Tropical Diseases, University Hospital in Krakow, Poland, from October 2018 to February 2020, and 28 healthy volunteers. All individuals were of Caucasian race. Infection was confirmed by detection of $C$. difficile antigen and toxins in feces using the TOX A/B Wampole Quick Check Complete test kit (TechLab Inc., Blacksburg, VA, USA). When the test came back positive for the antigen but negative for the toxin, the test for the $C$. difficile toxin was repeated with the $C$. difficile Toxin ELISA A/B II test kit (TechLab Inc., Blacksburg, VA, USA). A CDI case was defined as a patient with symptoms of CDI and positive laboratory test(s) according to the European Society of Clinical Microbiology and Infectious Diseases (ESCMID) guidelines [13]. Exclusion criteria included the presence of any CDI episode in control group, and the presence of acute or chronic inflammatory diseases in both groups. Patients with any infection in the control group, and any other infection than CDI in the CDI group were also excluded. All subjects had given their informed consent for inclusion before they participated in the study. The study was conducted in accordance with the Declaration of Helsinki (as revised in Brazil 2013). The study protocol was approved by the Ethics Committee of Jagiellonian University, ID number 1072.6120.211.2017.

\subsection{Blood Tests}

Blood samples were collected in the morning, between 7.00 and $8.00 \mathrm{a} . \mathrm{m}$. after an overnight fast. They were taken at the beginning of infection, no later than $48 \mathrm{~h}$ after CDI diagnosis. We assessed the following: complete blood count with differential leukocyte count, serum creatinine, albumin, and C-reactive protein (CRP) levels. All tests were performed according to generally accepted standard procedures.

\subsection{Gene Expression Assay}

Whole blood was collected into 5 mL EDTA-treated tubes. Buffy coat fractions were prepared by centrifugation of the collection tubes at $1500 \times \mathrm{g}$ for $15 \mathrm{~min}$ at room temperature. Next, the buffy coats were mixed in equal volume of DNA/RNA Shield ( $2 \times$ concentrate) (Zymo Research, Irvine, CA, USA) and samples were stored in $-80{ }^{\circ} \mathrm{C}$. RNA was isolated from $500 \mu \mathrm{L}$ of a sample by using the Quick-RNA ${ }^{\mathrm{TM}}$ Miniprep Plus Kit (Zymo Research, Irvine, CA, USA), following the manufacturer's instructions. One hundred and eighty nanograms of extracted RNA per sample were reverse-transcribed to cDNA by a High Capacity RNA-to-cDNA Kit (Applied Biosystems, Waltham, MA, USA). Quantitative RT-PCR was performed in triplicate with $2 \mu \mathrm{L}$ of cDNA, $1 \times$ TaqMan ${ }^{\circledR}$ 
Fast Advanced Master Mix and 1× TaqMan ${ }^{\circledR}$ Gene Expression assay HMGB1 (ID: Hs01923466_g1), glyceraldehyde-3-phosphate dehydrogenase GAPDH (ID: Hs02786624_g1), and actin beta ACTB (ID: Hs01060665_g1) (Applied Biosystems, Foster City, CA, USA) in a final reaction volume of $20 \mu \mathrm{L}$. Samples were amplified by the CFX96 Touch Real-Time PCR System (Bio-Rad, Pleasanton CA, USA) under the following thermal profile: initial incubation at $95^{\circ} \mathrm{C}$ for $2 \mathrm{~min}, 40$ cycles of denaturation at $95{ }^{\circ} \mathrm{C}$ for $1 \mathrm{~s}$ followed by annealing and extension at $60^{\circ} \mathrm{C}$ for $20 \mathrm{~s}$. Mean quantitation cycle (Cq) values of $H M G B 1$ were normalized to the geometric mean of GAPDH and ACTB, which were selected as stable, housekeeping genes [14-16]. Data were expressed for each sample as $\Delta \mathrm{Cq}$, which is the difference between the Cq HMGB1 value and the geometric mean of $\mathrm{Cq}$ values of GAPDH and ACTB for a particular sample.

\subsection{Statistical Analysis}

All data are presented as medians with lower $\left(\mathrm{Q}_{25}\right)$, and upper $\left(\mathrm{Q}_{75}\right)$ quartiles. Normal distribution of variables was analyzed using the Shapiro-Wilk test. Differences between study groups were determined using the Mann-Whitney test if normality was not observed. Correlation between selected variables was evaluated using Spearman's rank correlation. Calculations were performed using StatSoft, Inc. (2011), STATISTICA, version 13.3 statistical software licensed for Jagiellonian University, and statistical significance was defined as $p \leq 0.05$.

\section{Results}

The study group included 27 patients with mild or moderate CDI hospitalized at the Department of Infectious and Tropical Diseases, University Hospital, in Krakow, median age of 71 years, and 28 healthy volunteers median age of 69 years. Patients with CDI were found to have a significant increase in white blood cells (WBC), neutrophil count, and CRP levels, they also exhibited decreased levels of albumin compared with controls. HMGB1 gene expression was significantly lower in the CDI group compared with the control group (Table 1).

Table 1. Results of the assessed parameters in the study groups.

\begin{tabular}{|c|c|c|c|c|c|}
\hline \multirow{2}{*}{ Parameter } & \multicolumn{2}{|r|}{ CDI Group } & \multicolumn{2}{|r|}{ Control Group } & \multirow[t]{2}{*}{$P$} \\
\hline & $n$ & $\operatorname{Median}\left(\mathbf{Q}_{25}-\mathbf{Q}_{75}\right)$ & $n$ & Median $\left(Q_{25}-Q_{75}\right)$ & \\
\hline Age (years) & 27 & $71(67-84)$ & 28 & $69(65-72)$ & 0.17 \\
\hline $\mathrm{WBC}\left(\times 10^{3} / \mu \mathrm{L}\right)$ & 27 & $8.9(6.8-12.3)$ & 28 & $5.8(5.1-6.8)$ & $<0.001$ \\
\hline neutrophils $\left(\times 10^{3} / \mu \mathrm{L}\right)$ & 26 & $6.5(4.4-9.7)$ & 28 & $2.9(2.4-3.9)$ & $<0.001$ \\
\hline creatinine $(\mu \mathrm{mol} / \mathrm{L})$ & 27 & $82(58-121)$ & 28 & $76(69-90)$ & 0.49 \\
\hline albumin $(\mathrm{g} / \mathrm{L})$ & 25 & $28.6(24.1-33)$ & 20 & $40.3(34.9-41.9)$ & $<0.001$ \\
\hline CRP (mg/L) & 27 & $74(18-120)$ & 26 & $2.4(1-3.8)$ & $<0.001$ \\
\hline$\Delta \mathrm{Cq}$ & 27 & $3.71(3.44-4.09)$ & 28 & $3.25(3.02-3.35)$ & $<0.001$ \\
\hline Normalized Expression of $H M G B 1$ gene & 27 & $0.08(0.06-0.09)$ & 28 & $0.11(0.10-0.13)$ & $<0.001$ \\
\hline
\end{tabular}

Graphical representation of the data on HMGB1 gene expression is provided in Figure 1. 


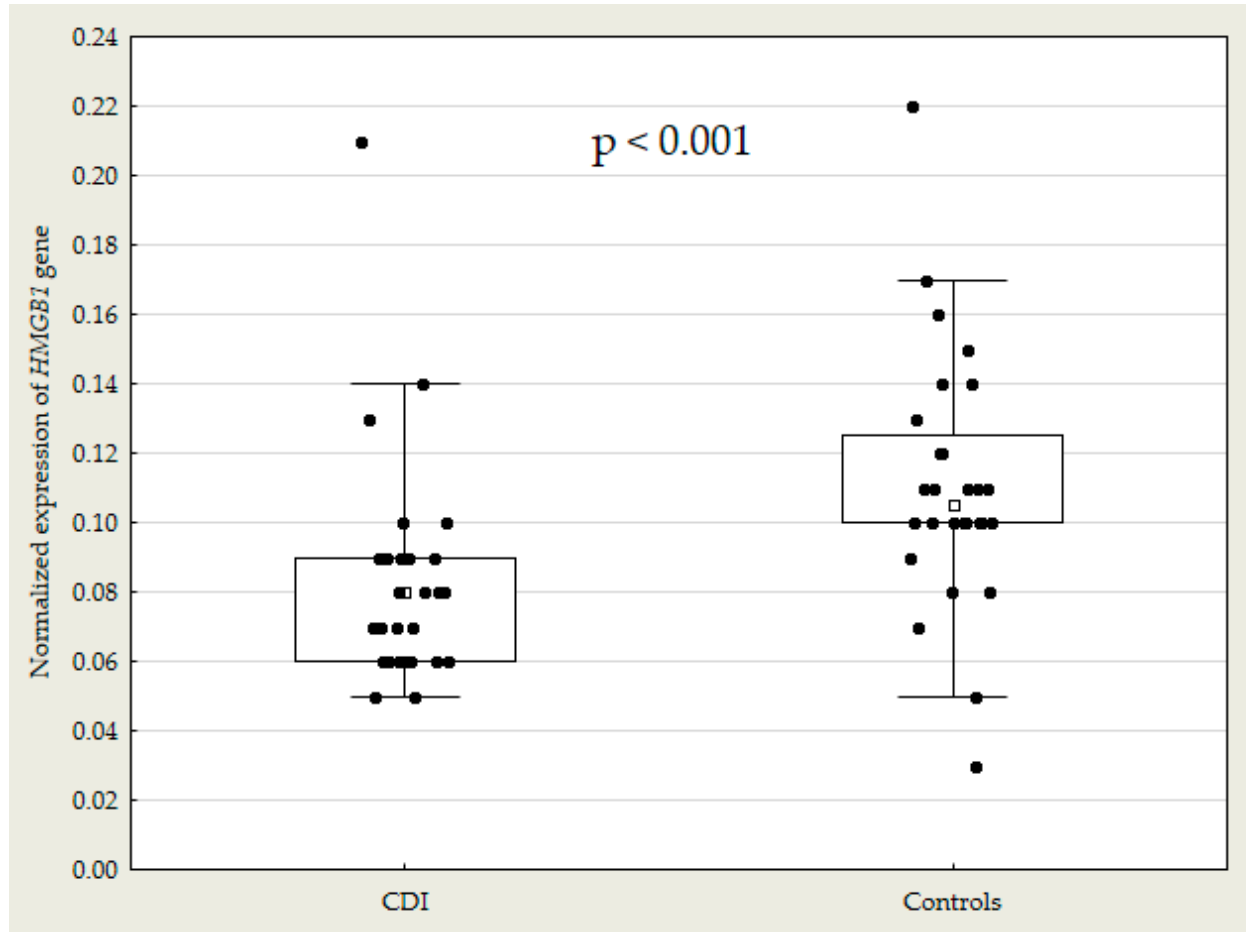

Figure 1. Normalized expression of HMGB1 gene in CDI $(n=27)$ and control $(n=28)$ groups. Box represents 25 th and 75 th percentile of values with median values marked within the boxes. Whiskers represent 5th-95th percentile. CDI, Clostridioides difficile infection; HMGB1, high-mobility group box 1 .

Next, a possible correlation between HMGB1 gene expression and the selected blood parameters was assessed. In the control group, as predicted, no significant correlation was found, whereas in the CDI group there was a statistically significant inverse relationship between HMGB1 gene expression and CRP level. No other significant relationships were found between the remaining parameters (Table 2). Research data are available as supplementary material.

Table 2. Correlations between HMGB1 gene expression and assessed blood parameters.

\begin{tabular}{ccccc}
\hline Parameter Correlated with HGMB1 Gene Expression & \multicolumn{2}{c}{ CDI Group } & \multicolumn{2}{c}{ Control Group } \\
\hline Parameters compared & $\mathrm{r}$ & $p$ & $\mathrm{r}$ & $p$ \\
\hline WBC & -0.29 & 0.14 & -0.16 & 0.41 \\
\hline Neutrophils & -0.18 & 0.39 & -0.28 & 0.16 \\
\hline Creatinine & -0.02 & 0.91 & -0.13 & 0.50 \\
\hline Albumin & 0.40 & 0.07 & 0.42 & 0.07 \\
\hline CRP & -0.42 & 0.03 & -0.09 & 0.67
\end{tabular}

CDI, Clostridioides difficile infection; CRP, C-reactive protein; HMGB1, high-mobility group box $1 ; p, p$ value; $\mathrm{r}$, correlation coefficient, WBC, white blood cells.

\section{Discussion}

\subsection{The Impact of Genetic Factors on the Course of Clostridioides Difficile Infection}

Studies assessing the impact of genetic factors on the course of CDI have, so far, been very few. Garey et al. demonstrated the correlation of region 251 of the IL-8 gene polymorphism with higher recurrence of CDI, and an increase in fecal IL-8 concentration [17]. Jiang et al. have shown in two studies that an AA genotype in the 251 position of IL8 is an important predictor of primary CDI $[18,19]$. 
In our previous study, we have shown that the presence of IL- $8+781 \mathrm{~T} / \mathrm{C}$ polymorphism is associated with the severity of CDI [20]. IL-8 is key in CDI pathogenesis, promoting chemotaxis of neutrophils to an infection site, which in turn initiates inflammation of the intestinal mucosa and emergence of symptoms [2,21]. The interleukin-4 associated single nucleotide polymorphism (SNP) rs2243250 has been associated with development of CDI in Inflammatory Bowel Disease (IBD) patients [22]. Jose et al. showed that homozygosity for leptin receptor Q223R SNP significantly increases the risk of peak peripheral WBC count $>20 \times 10^{9} / \mathrm{L}$, which is an indicator of adverse outcomes. They have also demonstrated in a murine model of CDI, that mice homozygous for the same SNP exhibit a higher leukocyte count in blood and tissue, exaggerated tissue inflammation and higher mortality, compared with control mice [23].

\subsection{The Role of HMGB1 in Clostridioides Difficile Infection}

HMGB1 plays an important role in the inflammatory process. It stimulates cell migration to an inflammation/injury site, which has been demonstrated on neural cells, smooth muscle cells, tumor cells, monocytes, and neutrophils [24-28]. It also aids in identification of bacterial products, boosting the innate immune response [29]. Through binding to cellular receptors, such as toll-like receptor 4 (TLR4), TLR9, and RAGE, HMGB1 activates innate immune cells, endothelial cells to produce proinflammatory cytokines, chemokines, tissue factor or adhesion molecules [10,29-33]. Furthermore, HMGB1 inhibits elimination through phagocytosis of apoptotic neutrophils, impeding resolution of inflammation [29]. So far, the role of HMGB1 has been established in inflammatory processes of conditions, such as arthritis, hepatitis, sepsis, rheumatoid arthritis, and systemic lupus erythematosus [34-36], as well as the pathogenesis of atherosclerosis and cancer [37,38].

However, studies examining the potential role of HMGB1 in CDI pathogenesis are lacking. It has been shown in vitro that HMGB1 may be involved in acute inflammation induced by the $C$. difficile toxin A. Liu et al. in their study demonstrated that HMGB1 is released from the nucleus into the cytoplasm and subsequently, extracellularly in response to C. difficile toxin A (TcdA). Pre-treatment with glycyrrhizin, an HMGB1 inhibitor, delays TcdA-induced cell rounding. Moreover, they have shown that inducing exogenous rHMGB1 increased MPO activity and intestinal injury in the 'ileal loop' surgical model. A statistically significant increase in mRNA expression of several proinflammatory cytokine genes (TNF- $\alpha$, IL-1 $\beta$, IL-6, keratinocyte chemoattractant-KC) in comparison to phosphate buffered saline (PBS) stimulation has been demonstrated. Interestingly, the effect observed after introducing rHMGB1 was similar to that of TcdA [39]. In another study the HMGB1 protein was involved in endoplasmic reticulum stress induced by the TcdA [9]. Gu et al. have shown that treatment with recombinant $C$. difficile toxin B (rTcdB) promotes the release of HMGB1 from CT26 cells in a time-dependent manner. The HMGB1 knockdown CT26 cells treated with rTcdB reduced their ability to produce IFN- $\gamma$, a cytokine important in CDI pathogenesis [40]. Chumbler et al. have shown that TcdB induces HMGB1 release from the HeLa cell line [41].

\subsection{HMGB1 Gene Expression in Different Infections}

Apart from the aforementioned study of Efron et al. [12], HMGB1 expression in CDI patients has been an underexplored subject. Studies delving into the changes in that expression in the course of different infections have, similarly, been few and far between. There has been an observed reduced expression of the HMGB1 gene in chronic Hepatitis B virus (HBV) infected patients, which hypothetically could lead to impaired DNA damage repair and favor development of hepatocellular carcinoma [42]. In contrast to that, an increased expression of the HGMB1 gene was observed in Hepatitis E virus (HEV) infected patients [15]. In bacterial infections, HMBG1 gene expression was assessed in active pulmonary tuberculosis, where it was increased in comparison to asymptomatic individuals tested for latent tuberculosis [43]. In an animal model of sepsis, expression levels of HMGB1 mRNA in the liver, lungs, kidneys, and small intestine of rats were markedly increased [44]. In another study, Herpes 
simplex type 2 virus (HSV-2) infection reduced HMGB1 expression in HEC-1 cells, derived from human endometrial cancer, which were used as a model of epithelial cells [45].

As mentioned above, genetic diversity may at least partially explain why the severity of symptoms varies so drastically in people similar in age and co-morbidities. In our study, the participants with CDI exhibited clear signs of infection, substantiated by the considerably increased values of WBC and CRP. HMGB1 is an important factor in the cellular defense response. It could be theorized that the observed decrease in expression of HMGB1 in CDI patients is a reflection of the system's diminished capability to fight the pathogen. That hypothesis is supported by the significant inverse correlation between HMGB1 expression and CRP demonstrated in our study. The lower the expression of HMGB1, the higher CRP was found in the blood. However, it remains unclear why the decrease in HMGB1 expression occurs, and whether it is a primary defect making that particular group of people vulnerable to developing symptoms of CDI or a secondary reaction based on a yet unexplained mechanism in the course of CDI. Further research into the subject is needed. In our study, we assessed the HMGB1 gene expression in the early phase of infection, which would further support the hypothesis of genetic predisposition towards CDI. Leaning on in vitro research, the increase in HMGB1 expression in the course of different infections was fast. In a study by Zhang et al. in an animal model of sepsis, this increase was detectable in $12 \mathrm{~h} \mathrm{[44].} \mathrm{Bearing} \mathrm{that} \mathrm{in} \mathrm{mind,} \mathrm{should} \mathrm{the} \mathrm{increase} \mathrm{in} \mathrm{HMGB1} \mathrm{gene}$ expression stem from the infection alone, it would be pronounced in our patients, as well. No such change in our study suggests, again, that it could be a primary defect making that particular group of people vulnerable to developing symptoms of CDI. Decreased expression of HMGB1 has also been observed in the course of HBV infection. It is worth noting that no significant changes were observed comparing acute HBV patients with healthy controls. Generally, only a minority of patients develop chronic hepatitis B, and, in the study by Mukherjee et al., only in this group was a decrease of HMGB1 gene expression observed. This observation supports the notion that a functioning HMGB1 gene may be an important element in combating HBV [42].

Fecal HMGB1 was found to be a marker of intestinal inflammation, as it was not only significantly increased in the stool of Inflammatory Bowel Disease (IBD) patients, compared with controls, but also indicative of the course of the disease. Moreover, HMGB1 was a very sensitive marker of persistent local gut inflammation in IBD patients with clinically quiescent disease [46,47]. In our study, we did not include patients with severe or fulminant CDI, but even in patients with mild or moderate CDI, a significant increase in CRP was observed, possibly indicating a systemic inflammatory response in addition to the local inflammation in the colon. Although we did not explore a possible association between the expression of HMGB1 and polymorphisms in this gene locus in our patients, such a relationship was theorized by many researchers. Kornblit et al. postulated this relationship based on in silico modeling, while others demonstrated it in pneumonia and cancer [48-50]. Several polymorphisms in gene loci of microRNAs regulating HMGB1 expression were also identified [51].

The main limitation of our study was that we did not include patients with severe CDI. Secondly, we measured the HMGB1 gene expression only at a single time point of infection. Moreover, we cannot exclude the possibility that CRP level is not a comprehensive marker of systemic inflammation in our patients due to potential co-morbidities with an inflammatory component, such as autoimmune diseases, pericarditis, tissue injuries, and other relatively commonly observed conditions. This may require careful exclusion of such co-morbidities in future study cohorts or inclusion of only those patients who are at the stage of remission while being recruited for a potential study of a similar scope.

\section{Conclusions}

We observed a decreased expression of the HMGB1 gene in peripheral blood of patients with mild or moderate CDI, which hypothetically could reflect their diminished capability to fight the pathogen. Future investigations should also include patients with severe CDI. It would be beneficial to assess whether the expression of $H M G B 1$ changes at other time points of infection, especially at the onset and toward the end of infection. 
Supplementary Materials: The following are available online at http://www.mdpi.com/2076-2607/8/8/1217/s1, Research data.

Author Contributions: Conceptualization J.C., P.P.W.; Formal analysis, J.C.; Funding acquisition, J.C.; Investigation, J.C., E.P.; Project administration, J.C.; Supervision, J.C.; Visualization, J.C.; Writing-original draft, J.C.; Writing-review \& editing, J.C., G.B., E.P., P.P.W., M.M., A.G. All authors have read and agreed to the published version of the manuscript.

Funding: This project was supported by the Polish Ministry of Science and Higher Education (the project of corresponding author Jacek Czepiel, N41/DBS/000284).

Conflicts of Interest: The authors declare no conflict of interest.

\section{References}

1. Lawson, P.A.; Citron, D.M.; Tyrrell, K.L.; Finegold, S.M. Reclassification of Clostridium difficile as Clostridioides difficile (Hall and O'Toole 1935) Preevot 1938. Anaerobe 2016, 40, 95-99. [CrossRef] [PubMed]

2. Penichea, A.G.; Savidge, T.C.; Dann, S.M. Recent insights into Clostridium difficile pathogenesis. Curr. Opin. Infect. Dis. 2013, 26, 447-453. [CrossRef] [PubMed]

3. Czepiel, J.; Dróżdż, M.; Pituch, H.; Kuijper, E.J.; Perucki, W.; Mielimonka, A.; Goldman, S.; Wultańska, D.; Garlicki, A.; Biesiada, G. Clostridium difficile infection: Review. Eur. J. Clin. Microbiol. Infect. Dis. 2019, 38, 1211-1221. [CrossRef]

4. Clabots, C.R.; Johnson, S.; Olson, M.; Peterson, L.R.; Gerding, D.N. Acquisition of Clostridium difficile by hospitalized patients: Evidence for colonized new admissions as a source of infection. J. Infect. Dis. 1992, 166, 561-567. [CrossRef] [PubMed]

5. Marciniak, C.; Chen, D.; Stein, A.C.; Semik, P.E. Prevalence of Clostridium difficile colonization at admission to rehabilitation. Arch. Phys. Med. Rehabil. 2006, 87, 1086-1090. [CrossRef] [PubMed]

6. Hung, Y.P.; Lee, L.C.; Lin, H.J.; Liu, H.C.; Wu, Y.H.; Tsai, P.J.; Ko, W.C. Clinical impact of Clostridium difficile colonization. J. Microbiol. Immunol. Infect. 2015, 48, 241-248. [CrossRef]

7. Hensgens, M.P.M.; Keessen, E.C.; Squire, M.M.; Riley, T.V.; Koene, M.G.; de Boer, E.; Lipman, L.J.; Kuijper, E.J. Clostridium difficile infection in the community: A zoonotic disease? Clin. Microbiol. Infect. 2012, 18, 635-645. [CrossRef]

8. Leffler, D.A.; Lamont, J.T. Clostridium difficile infection. N. Engl. J. Med. 2015, 373, 287-288. [CrossRef]

9. Liu, J.; Ma, Y.; Sun, C.L.; Li, S.; Wang, J.F. High Mobility Group Box1 protein is involved in endoplasmic reticulum stress induced by Clostridium difficile toxin A. Biomed. Res. Int. 2016, 2016. [CrossRef]

10. Bellussi, L.M.; Cocca, S.; Passali, G.C.; Passali, D. HMGB1 in the pathogenesis of nasal inflammatory diseases and its inhibition as new therapeutic approach: A review from the literature. Int. Arch. Otorhinolaryngol. 2017, 21, 390-398. [CrossRef]

11. Yamada, S.; Maruyama, I. HMGB1, a novel inflammatory cytokine. Clin. Chim. Acta 2007, 375, 36-42. [CrossRef] [PubMed]

12. Efron, P.A.; Liu, H.; Lottenberg, L.; Cuenca, A.G.; Gentile, L.F.; Miggins, M.V.; Bihorac, A.; Baker, H.V.; Moore, F.A.; Moldawer, L.L.; et al. A genomic analysis of Clostridium difficile infections in blunt trauma patients. J. Trauma Acute Care Surg. 2013, 74, 334-338. [CrossRef] [PubMed]

13. Debast, S.B.; Bauer, M.P.; Kuijper, E.J.; ESCMID. European Society of Clinical Microbiology and Infectious Diseases: Update of the treatment guidance document for Clostridium difficile infection. Clin. Microbiol, Infect. 2014, 20, 1-26. [CrossRef] [PubMed]

14. Ding, Y.; Chu, C.; Li, Y.; Li, G.; Lei, X.; Zhou, W.; Chen, Z. High expression of HMGB1 in children with refractory Mycoplasma pneumoniae pneumonia. BMC Infect. 2018, 18, 439. [CrossRef]

15. Majumdar, M.; Ratho, R.; Chawla, Y.; Singh, M.P. High levels of circulating HMGB1 as a biomarker of acute liver failure in patients with viral hepatitis E. Liver Int. 2013, 33, 1341-1348. [CrossRef]

16. Mohajertehran, F.; Ayatollahi, H.; Khazaeni, K.; Shakeri, M.T.; Mohtasham, N. Overexpression of High-Mobility Motor Box 1 in the blood and tissues of patients with head and neck squamous cell carcinoma. Iran. J. Otorhinolaryngol. 2018, 30, 261-271.

17. Garey, K.W.; Jiang, Z.D.; Ghantoji, S.; Tam, V.H.; Arora, V.; DuPont, H.L. A common polymorphism in the Interleukin-8 gene promoter is associated with an increased risk for recurrent Clostridium difficile infection. Clin. Infect. Dis. 2010, 51, 1406-1410. [CrossRef] 
18. Jiang, Z.D.; DuPont, H.L.; Garey, K.; Price, M.; Graham, G.; Okhuysen, P.; Dao-Tran, T.; LaRocco, M. A common polymorphism in the interleukin 8 gene promoter is associated with Clostridium difficile diarrhea. Am. J. Gastroenterol. 2006, 101, 1112-1116. [CrossRef]

19. Jiang, Z.D.; Garey, K.W.; Price, M.; Graham, G.; Okhuysen, P.; Dao-Tran, T.; LaRocco, M.; DuPont, H.L. Association of interleukin-8 polymorphism and immunoglobulin G anti-toxin A in patients with Clostridium difficile-associated diarrhea. Clin. Gastroenterol. Hepatol. 2007, 5, 964-968. [CrossRef]

20. Czepiel, J.; Biesiada, G.; Dróżdż, M.; Gdula-Argasińska, J.; Żurańska, J.; Marchewka, J.; Perucki, W.; Wołkow, P.; Garlicki, A. The presence of IL- $8+781$ T/C polymorphism is associated with the parameters of severe Clostridium difficile infection. Microb. Pathog. 2018, 114, 281-285. [CrossRef]

21. Madan, R.; Petri, W.A., Jr. Immune responses to Clostridium difficile infection. Trends Mol. Med. 2012, 18, 658-666. [CrossRef] [PubMed]

22. Connelly, T.M.; Koltun, W.A.; Sangster, W.; Berg, A.S.; Hegarty, J.P.; Harris, L., III; Deiling, S.; Stewart, D.B. An interleukin-4 polymorphism is associated with susceptibility to Clostridium difficile infection in patients with inflammatory bowel disease: Results of a retrospective cohort study. Surgery 2014, 156, 769-775. [CrossRef] [PubMed]

23. Jose, S.; Abhyankar, M.M.; Mukherjee, A.; Xue, J.; Andersen, H.; Haslam, D.B.; Madan, R. Leptin receptor Q223R polymorphism influences neutrophil mobilization after Clostridium difficile infection. Mucosal Immunol. 2018, 11, 947-957. [CrossRef] [PubMed]

24. Fages, C.; Nolo, R.; Huttunen, H.J.; Eskelinen, E.; Rauvala, H. Regulation of cell migration by amphoterin. J. Cell Sci. 2000, 113, 611-620. [PubMed]

25. Degryse, B.; Bonaldi, T.; Scaffidi, P.; Müller, S.; Resnati, M.; Sanvito, F.; Arrigoni, G.; Bianchi, M.E. The high mobility group (HMG) boxes of the nuclear protein HMG1 induce chemotaxis and cytoskeleton reorganization in rat smooth muscle cells. J. Cell Biol. 2001, 152, 1197-1206. [CrossRef] [PubMed]

26. Huttunen, H.J.; Fages, C.; Kuja-Panula, J.; Ridley, A.J.; Rauvala, H. Receptor for advanced glycation end products-binding $\mathrm{COOH}$-terminal motif of amphoterin inhibits invasive migration and metastasis. Cancer Res. 2002, 62, 4805-4811.

27. Rouhiainen, A.; Kuja-Panula, J.; Wilkman, E.; Pakkanen, J.; Stenfors, J.; Tuominen, R.K.; Lepäntalo, M.; Carpén, O.; Parkkinen, J.; Rauvala, H. Regulation of monocyte migration by amphoterin (HMGB1). Blood 2004, 104, 1174-1182. [CrossRef]

28. Orlova, V.V.; Choi, E.Y.; Xie, C.; Chavakis, E.; Bierhaus, A.; Ihanus, E.; Ballantyne, C.M.; Gahmberg, C.G.; Bianchi, M.E.; Nawroth, P.P.; et al. A novel pathway of HMGB1-mediated inflammatory cell recruitment that requires Mac-1-integrin. EMBO J. 2007, 26, 1129-1139. [CrossRef]

29. Zhu, S.; Li, W.; Ward, M.F.; Sama, A.E.; Wang, H. High mobility group box 1 protein as a potential drug target for infection- and injury-elicited inflammation. Inflamm. Allergy Drug Targets 2010, 9, 60-72. [CrossRef]

30. Yamoah, K.; Brebene, A.; Baliram, R.; Inagaki, K.; Dolios, G.; Arabi, A.; Majeed, R.; Amano, H.; Wang, R.; Yanagisawa, R.; et al. High-mobility group box proteins modulate tumor necrosis factor-alpha expression in osteoclastogenesis via a novel deoxyribonucleic acid sequence. Mol. Endocrinol. 2008, 22, 1141-1153. [CrossRef]

31. Pedrazzi, M.; Patrone, M.; Passalacqua, M.; Ranzato, E.; Colamassaro, D.; Sparatore, B.; Pontremoli, S.; Melloni, E. Selective proinflammatory activation of astrocytes by high-mobility group box 1 protein signaling. J. Immunol. 2007, 179, 8525-8532. [CrossRef] [PubMed]

32. Fiuza, C.; Bustin, M.; Talwar, S.; Tropea, M.; Gerstenberger, E.; Shelhamer, J.H.; Suffredini, A.F. Inflammation-promoting activity of HMGB1 on human microvascular endothelial cells. Blood 2003, 101, 2652-2660. [CrossRef] [PubMed]

33. Lv, B.; Wang, H.; Tang, Y.; Fan, Z.; Chen, F.; Xiao, X. High-mobility group box 1 protein induces tissue factor expression in vascular endothelial cells via activation of NF-kappaB and Egr-1. Thromb. Haemost. 2009, 102, 352-359. [PubMed]

34. Lotze, M.T.; Tracey, K.J. High-mobility group box 1 protein (HMGB1): Nuclear weapon in the immune arsenal. Nat. Rev. Immunol. 2005, 5, 331-342. [CrossRef] [PubMed]

35. Wittemann, B.; Neuer, G.; Michels, H.; Truckenbrodt, H.; Bautz, F.A. Autoantibodies to nonhistone chromosomal proteins HMG-1 and HMG-2 in sera of patients with juvenile rheumatoid arthritis. Arthritis Rheum. 1990, 33, 1378-1383. [CrossRef] 
36. Popovic, K.; Ek, M.; Espinosa, A.; Padyukov, L.; Harris, H.E.; Wahren-Herlenius, M.; Nyberg, F. Increased expression of the novel proinflammatory cytokine high mobility group box chromosomal protein 1 in skin lesions of patients with lupus erythematosus. Arthritis Rheum. 2005, 52, 3639-3645. [CrossRef]

37. Porto, A.; Palumbo, R.; Pieron, M.; Aprigliano, G.; Chiesa, R.; Sanvito, F.; Maseri, A.; Bianchi, M.E.; Porto, A.; Palumbo, R.; et al. Smooth muscle cells in human atherosclerotic plaques secrete and proliferate in response to high mobility protein box 1. FASEB J. 2006, 20, E1-E9. [CrossRef]

38. Vakkila, J.; Lotze, M.T. Inflammation and necrosis promote tumor growth. Nat. Rev. Immunol. 2004, 4, 641-648. [CrossRef]

39. Liu, J.; Zhang, B.L.; Sun, C.L.; Wang, J.; Li, S.; Wang, J.F. High mobility group box 1 protein is involved in acute inflammation induced by Clostridium difficile toxin A. Acta Biochim. Biophys. Sin. 2016, 48, 554-562. [CrossRef]

40. Gu, H.; Liu, J.; Chen, S.; Qi, H.; Shi, K.; Li, S.; Ma, Y.; Wang, J. High-mobility group box 1 protein contributes to the immunogenicity of rTcdB-treated CT26 cells. Acta Biochim. Biophys. Sin. 2018, 50, 921-928. [CrossRef]

41. Chumbler, N.M.; Farrow, M.A.; Lapierre, L.A.; Franklin, J.L.; Haslam, D.; Goldenring, J.R.; Lacy, D.B. Clostridium difficile toxin B causes epithelial cell necrosis through an autoprocessing-independent mechanism. PLoS Pathog. 2012, 8. [CrossRef]

42. Mukherjee, R.M.; Shravanti, G.V.; Jakkampudi, A.; Kota, R.; Jangala, A.L.; Reddy, P.B.; Rao, P.N.; Gupta, R.; Reddy, D.N. Reduced expression of DNA damage repair genes High Mobility Group Box1 and Poly(ADP-ribose) Polymerase1 in inactive carriers of hepatitis B virus infection-A possible stage of viral integration. J. Clin. Exp. Hepatol. 2013, 3, 89-95. [CrossRef] [PubMed]

43. Lui, G.; Wong, C.K.; Ip, M.; Chu, Y.J.; Yung, I.M.; Cheung, C.S.; Zheng, L.; Lam, J.S.; Wong, K.T.; Sin, W.W.; et al. HMGB1/RAGE signaling and pro-inflammatory cytokine responses in non-HIV adults with active pulmonary tuberculosis. PLoS ONE 2016, 11. [CrossRef] [PubMed]

44. Zhang, L.; Yao, Y.; Lu, J.; Yan, X.J.; Yu, Y.; Sheng, Z.Y. Recombinant bactericidal/permeability-increasing protein inhibits endotoxin-induced High Mobility Group Box1 gene expression in sepsis. Shock 2008, 29, 278-284. [CrossRef] [PubMed]

45. Borde, C.; Barnay-Verdier, S.; Gaillard, C.; Hocini, H.; Maréchal, V.; Gozlan, J. Stepwise release of biologically active HMGB1 during HSV-2 infection. PLoS ONE 2011, 6. [CrossRef] [PubMed]

46. Vitali, R.; Stronati, L.; Negroni, A.; Di Nardo, G.; Pierdomenico, M.; Del Giudice, E.; Rossi, P.; Cucchiara, S. Fecal HMGB1 is a novel marker of intestinal mucosal inflammation in pediatric inflammatory bowel disease. Am. J. Gastroenterol. 2011, 106, 2029-2040. [CrossRef]

47. Palone, F.; Vitali, R.; Cucchiara, S.; Pierdomenico, M.; Negroni, A.; Aloi, M.; Nuti, F.; Felice, C.; Armuzzi, A.; Stronati, L. Role of HMGB1 as a suitable biomarker of subclinical intestinal inflammation and mucosal healing in patients with inflammatory bowel disease. Inflamm. Bowel Dis. 2014, 20, 1448-1457. [CrossRef]

48. Kornblit, B.; Munthe-Fog, L.; Petersen, S.L.; Madsen, H.O.; Vindeløv, L.; Garred, P. The genetic variation of the human HMGB1 gene. Tissue Antigens 2007, 70, 151-156. [CrossRef]

49. Song, W.; Tan, H.; Wang, S.; Zhang, Y.; Ding, Y. Association of High Mobility Group Box Protein B1 gene polymorphisms with pneumonia susceptibility and severity. Genet. Test. Mol. Biomark. 2019, 23, 3-11. [CrossRef]

50. Wang, J.; Zhu, J.; Mao, D.H.; Zhu, S.; Mi, X.G.; Yu, Q. An indel polymorphism in the 3' untranslated region of HMGB1 confers risk for hepatocellular carcinoma by regulating HMGB1 transcriptional activity in a Chinese population. Neoplasma 2020, 67,61-67. [CrossRef]

51. Issac, M.S.M.; Girgis, M.; Haroun, M.; Shalaby, A. Association of genetic polymorphism of pre-microRNA-146a rs2910164 and serum High-Mobility Group Box 1 with febrile seizures in Egyptian children. J. Child Neurol. 2015, 30, 437-444. [CrossRef] [PubMed]

(C) 2020 by the authors. Licensee MDPI, Basel, Switzerland. This article is an open access article distributed under the terms and conditions of the Creative Commons Attribution (CC BY) license (http://creativecommons.org/licenses/by/4.0/). 